\title{
Ultralyd kan vurdere sykdomsaktivitet ved tarmsykdommen Crohn
}

Fredrik Bjorvatn Sævik ved klinisk institutt 1 ved Universitetet i Bergen forsvarte den 21. september 2020 sin avhandling for graden philosophiae doctor (PhD).

\section{Avhandlingens tittel:}

"Ultrasonographic evaluation of disease activity in Crohn's Disease”

\section{Sammendrag:}

Crohns sykdom er en kronisk betennelsessykdom som kan ramme hele mage-tarmkanalen. Sykdommen svinger typisk mellom remisjon og oppbluss av sykdomsaktivitet, men det er ikke alltid samsvar mellom pasientens symptomer og graden av betennelsesaktivitet. Derfor nyttes vanligvis koloskopi som et objektivt mål på sykdomsaktivitet. Hyppig monitorering med koloskopi ville derfor være en optimal måte å følge opp denne pasientgruppen. Koloskopi har imidlertid flere begrensninger, er ressurskrevende og ubehagelig for pasienter, noe som begrenser bruken. Det er derfor behov for enkle, ikke-invasive og billigere metoder.

Tarmultralyd har vist seg å ha god følsomhet for sykdomsdeteksjon. Metoden er videre pasientvennlig og kan utføres relativt hurtig, og er derfor velegnet for gjentatte undersøkelser. Likevel er metoden lite brukt i oppfølging av pasienter med Crohns sykdom.

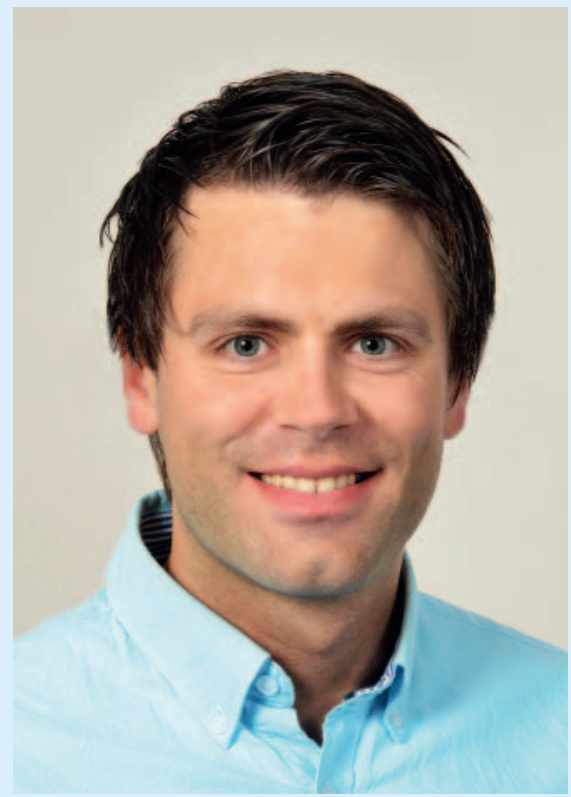

Fredrik Bjorvatn Sævik

Gjennom tre arbeider som presenteres i avhandlingen demonstrerer vi ultralydmetodens evne til å vurdere sykdomsaktiviteten hos pasienter med Crohns sykdom. I den første studien ble det funnet at tidlig vurdering med kontrastforsterket ultralyd kan brukes til å forutsi om igangsatt behandling vil være effektiv eller ikke, der lav tarmperfusjon etter en måned indikerer behandlingseffekt. I den andre studien vises at ultralyd samsvarer godt med koloskopi når det gjelder å skille mellom remisjon og aktiv

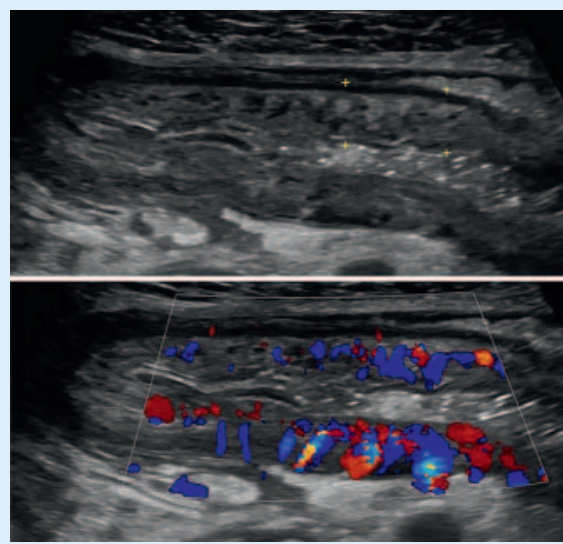

Pasient med aktiv Crohns sykdom med veggtykkelse ca $7 \mathrm{~mm}$ (øverste bilde) og kraftig Doppleroppladning i tarmveggen (nederste bilde).

sykdom, med høy interobserver-reliabilitet. I den siste studien ble det utviklet og validert et enkelt ultralydbasert skåringssystem for å vurdere grad av sykdomsaktivitet på totalt 164 pasienter. Skåringssystemet samsvarte godt med koloskopi og hadde høy interobserver-reliabilitet.

Avhandlingen konkluderer med at ultralyd er en nøyaktig metode for å kvantifisere betennelsesaktivitet ved Crohn sykdom. Ved å benytte ultralyd regelmessig i oppfølgingen av denne pasientgruppen kan en systematisk følge sykdomsaktivitet og dermed potensielt forbedre valg av behandling. 